\title{
Application of response surface methodology as mathematical and statistical tools in natural product research
}

\author{
Florentinus Dika Octa Riswanto ${ }^{1,2}$, Abdul Rohman $^{2}$, Suwidjiyo Pramono ${ }^{3}$, Sudibyo Martono ${ }^{2 *}$ \\ 'Department of Pharmacy, Faculty of Pharmacy, Sanata Dharma University, Campus III Paingan, Maguwoharjo, Depok, Sleman, \\ Yogyakarta 55282 Indonesia. \\ ${ }^{2}$ Department of Pharmaceutical Chemistry, Faculty of Pharmacy, Gadjah Mada University, Yogyakarta, 55281, Indonesia. \\ ${ }^{3}$ Department of Pharmaceutical Biology, Faculty of Pharmacy, Gadjah Mada University, Yogyakarta, 55281, Indonesia.
}

\section{ARTICLE INFO \\ Received on: 20/06/2019 \\ Accepted on: 20/08/2019 \\ Available online: 05/10/2019}

\section{Key words:}

Box-Behnken design, central composite design, Doehlert design, factorial

design, response surface

methodology.

\begin{abstract}
Response Surface Methodology (RSM) models combined with experimental designs became popular in recent years. Their advantages to analyze the interactive effects among different factors and the efficiency considerations encouraged more researchers to conduct natural product research employed with these models. A review about basic principles of factorial designs, central composite designs, Box-Behnken designs, and Doehlert designs which utilized along with the RSM and their applications in natural product research is presented. The objective of this review was to report various experimental design techniques and their applications in the field of natural product research. Furthermore, the characteristic of each design is also presented and the trends of RSM applications in natural product research are also discussed in this paper.
\end{abstract}

\section{INTRODUCTION}

Natural products can be described as products achieved from various natural sources such as plants, microbes, and animals. An entire organism, a part of an organism, an extract from an organism or part of an organism and an exudate, and pure compound are categorized as natural products (Sarker and Nahar, 2007). Secondary metabolites as non-essential small biomolecules from natural products were studied during thousands of years due to their various functions, depending on the origin organism with several variations of the origin, organism's habitat, and organism's activity (Bernardini et al., 2018). Secondary metabolites are classified into five types, namely, alkaloids, fatty acid-derived substances and polyketides, terpenoids and steroids, non-ribosomal polypeptides, and enzyme cofactors (Thirumurugan et al., 2018). Further, the

"Corresponding Author

Sudibyo Martono, Department of Pharmaceutical Chemistry,

Faculty of Pharmacy, Gadjah Mada University, Yogyakarta, 55281,

Indonesia.E-mail: sudibyo_martono@ugm.ac.id rapid development of genomics research leads to metabolomics studies which become a powerful tool for discovering and producing secondary metabolite (Breitling et al., 2013).

In the last four decades, the interest for discovering and developing new drugs from natural products has increased significantly (Li and Lou, 2018; Newman and Cragg, 2016). Natural products played important roles to solve several health problems as anti-inflammatory agent (Mahdi, 2010), analgesic agent (SoaresBezerra et al., 2013), anticancer agent (Handayani and Aminah, 2017; Puspita et al., 2019; Yuliani et al., 2016), antibiotics (Moloney, 2016), anti-angiogenic agent (Aghamohammadi and Hosseinimehr, 2014), antibiofilm (Hamzah et al., 2018), antimalarial drugs (Mojab, 2012), antileukemic agent (Newman et al., 2000), etc. Sources of natural product in drug discovery varied from fungi, plants, marine environment, marine algae, marine sponges, and other marine sources (Dias et al., 2012). Nature is not only providing a new source of drugs but also providing sources for foods (Parodi et al., 2018). There are many different nutrients such as carbohydrates, fats, proteins, minerals, and vitamins that can be achieved by eating 
good meals from natural products (Abdel-Rahman et al., 2011; Burgess and Glasauer, 2004).

Natural products research can become promising in the field of drug discovery and essential future foods development, but there still remain several challenges to be faced by the academic and industrial researcher (Hunter-Cevera et al., 2014). Questions related to active compounds, action mechanism, pharmacology-toxicology aspects, and drugs interaction were frequently asked to ensure the pharmacological effects as well as clinical results (Shan et al., 2007). Hence, it is important to perform standardization and optimization process to evaluate active compounds content (Yuliani et al., 2016), extraction process (Yuliani et al., 2018), computational screening and design (Riswanto et al., 2017), formulation composition (Benali et al., 2014), analytical method validation (Choi et al., 2018), laboratory conditions (Jeong et al., 2017), and instrument settings (Siregar et al., 2017).

Currently, integration of technology and mathematical techniques can be employed to overcome several scientific problems both for education and research (Luneeva and Zakirova, 2017). Since analytical instrument could produce a lot of data and many factors might affect the complexity of experimental results, experimental design as one of chemometrics method can be applied and become the best choice for performing data optimization (Miller and Miller, 2010). Experimental design is commonly used to explain the process of identifying, designing, and evaluating experimental factors statistically (Miller and Miller, 2010; Vera-Candioti et al., 2014). Table 1 exhibits list of the most commonly used design of experiments for optimization study. Response surface methodology (RSM), a special type of experimental design, can be described as a collection of both mathematical and statistical techniques for designing, developing, improving, optimizing, and formulating of product designs where several variables potentially affect characteristics of products designs (Myers et al., 2009). This method improved the traditional optimization which has been carried out by evaluating the effect of one-variable-at-a-time. RSM has the capability to analyze the interactive effects among the variables and minimize ineffective time and reagent used for a research project (Bezerra et al., 2008).
It is necessary to choose an appropriate experimental design before applying RSM. This present review paper discusses various experimental designs with different basic principles and applications in natural product research.

\section{METHODS}

Relevant information in the field of natural product research, herbal chemistry, computational statistics, and RSM applications were investigated and assembled from several sources such as Google Scholar, Elsevier, Science Direct, Pubmed, SciFinder, Scopus, and Web of Science. Supporting references sourced from journal articles, books, theses, and scientific reports were accessed using facilities provided by Gadjah Mada University, Indonesia. The literature search was carried out between March and June 2019. The keywords used in the literature search included "natural product," "response surface methodology," "experimental design," "factorial design," "BoxBehnken design (BBD)," "central composite design (CCD)," and "Doehlert design".

\section{FACTORIAL DESIGN}

The term factorial design is defined as an experimental design in which combinations of levels of factors were set as the runs (Hibbert, 2012). Factorial design was categorized as full factorial design and fractional factorial design which both of them with two levels for each factor $(k)$ were commonly used in process of screening design due to their efficiency and economical consideration (Vera-Candioti et al., 2014). It is possible to combine every factor at the designed level using full factorial design as $L^{k}$ combinations, where $k$ represents number of factors and $L$ represents designed levels. On the other hand, the fractional factorial design only evaluates a specific subset of a full design. Fractional factorial design enables the evaluation of a relatively large number of factor in small number of runs or experiments. This method was designed by fractioning a full factorial design of $L^{k}$ combinations into $L^{k-p}$ combinations, where $p$ represents the number of independent design generators. It should be noted that the fractional factorial design can reduce the number of runs or experiments but it does not possible to estimate all major and

Table 1. Design of experiments for common optimization study.

\begin{tabular}{|c|c|c|c|c|}
\hline Design & Factor levels & $\begin{array}{c}\text { Number of } \\
\text { experiments }\end{array}$ & RSM & Characteristics \\
\hline \multicolumn{5}{|l|}{ Factorial design (FD) } \\
\hline Two-level full factorial (2-FFD) & $2 \leq k \leq 5$ & $\begin{array}{l}2^{k} \text { or } 2^{k+1} \\
\text { (considering replicates) }\end{array}$ & No & Commonly used for screening study. \\
\hline Two-level fractional factorial & $>4$ & $2^{k-p}$ & No & $\begin{array}{l}\text { Commonly used for screening study with a } \\
\text { smaller number of runs. }\end{array}$ \\
\hline Three-level full factorial (3-FFD) & 3 & $3^{k}$ & Yes & Requires a large number of runs. \\
\hline \multirow[t]{2}{*}{ Central composite design (CCD) } & 5 & $2^{k}+2^{k}+C p$ & Yes & $\begin{array}{l}\text { - All factors are studied in five levels } \\
(-\alpha,-1,0,+1,+\alpha)\end{array}$ \\
\hline & & & & $\begin{array}{l}\text { - } \alpha \text {-values can be calculated using the formula of } \\
\alpha=2^{(k-p) / 4}\end{array}$ \\
\hline \multirow[t]{2}{*}{ Box-Behnken design (BBD) } & 3 & $2 k(k-1)+C p$ & Yes & $\begin{array}{l}\text { - All factors should be adjusted in three levels } \\
(-1,0,+1) \text {. }\end{array}$ \\
\hline & & & & - No factorial or extreme points. \\
\hline Doehlert design (DD) & $\begin{array}{l}\text { Depend on each } \\
\text { factor }\end{array}$ & $k^{2}+k+C p$ & Yes & Factor levels are different for each factor. \\
\hline
\end{tabular}

$k=$ number of factors; $p=$ number of independent generators; $C p=$ the replicate number of the central point; $\alpha=$ star point location determinator. 
interaction effect separately (Brereton, 2007; Hibbert, 2012). However, only full factorial designs at three levels can be applied in conjunction with the RSM by running $3^{k}$ experiments. Figure 1 illustrates the model of factorial design at various levels.

Table 2 presents some studies employed by the factorial design. Portilla-Rivera et al. (2009) performed a fractional factorial design in order to study the relationship between the type and the ratio of hemicellulosic sugars (Portilla-Rivera et al., 2009). An incomplete/fractional $3^{3}$ factorial design has been developed to study the effect of glucose, xylose, and arabinose on the production of surface-active compounds by Lactobacillus pentosus. This study resulted in the optimum ratio of xylose/ glucose was 1.5-3.5 for producing biosurfactants achieved from the trimming vine shoots or grape marc. Fractional factorial designs were also useful for extraction optimization both for Salvia mirzayanii (Khajeh and Ghanbari, 2011) and Artemisia annua (Khalil et al., 2011). Khajeh and Ghanbari (2011) developed a two-level fractional factorial design $\left(2^{4-1}\right)$ based on an analysis of variance to evaluate the significance of microwave power, temperature, time, and type before performing a BBD for optimizing the extraction condition of $S$. mirzayanii oil. Another study by Khalil et al. (2011) developed a three-level fractional factorial design $\left(3^{\mathrm{k}-1}\right)$ for extraction of artemisinin. The optimum condition was achieved by sample immersion in chloroform for 2 minutes with the ratio of sample/solvent of $0.5 / 3 \mathrm{~g} / \mathrm{ml}$.
Full factorial designs were also used for several studies with similar optimization purpose such as evaluating the extraction process or taking part in screening models of optimization. Setyawan et al. (2018) optimized the extraction condition of Camellia sinensis L. using a full two-level and twofactor factorial design. The optimum condition was achieved with the water temperature of $95^{\circ} \mathrm{C}$ and two-times brewing number. Other studies developed full two-level and three-factor factorial designs for evaluating both the preparation process and extraction condition for natural products such as Ginger rhizome (Shah and Garg, 2014), Lippia sidoides (Lima et al., 2015), and a fermented product from soybean called tempeh (Yuliani et al., 2018). As reported, the fractional and full factorial designs were widely used in optimization and design screening studies because of their economic advantages and efficiency. Nevertheless, the RSM model was only applicable to be performed along with full three or more level factorial designs due to their ability to generate all possible combinations from a data set of factors in order to investigate the effects of all factors and interaction (Sen, 2016).

RSM is suitable for fitting a quadratic surface in order to optimize process parameters. Further, the RSM strongly supported the experimental studies to determine the optimum process (Behera et al., 2018). The full three-level factorial design with RSM has been performed by de Aragão et al. (2005) and Saccani et al. (2005) to optimize chromatographic separation.
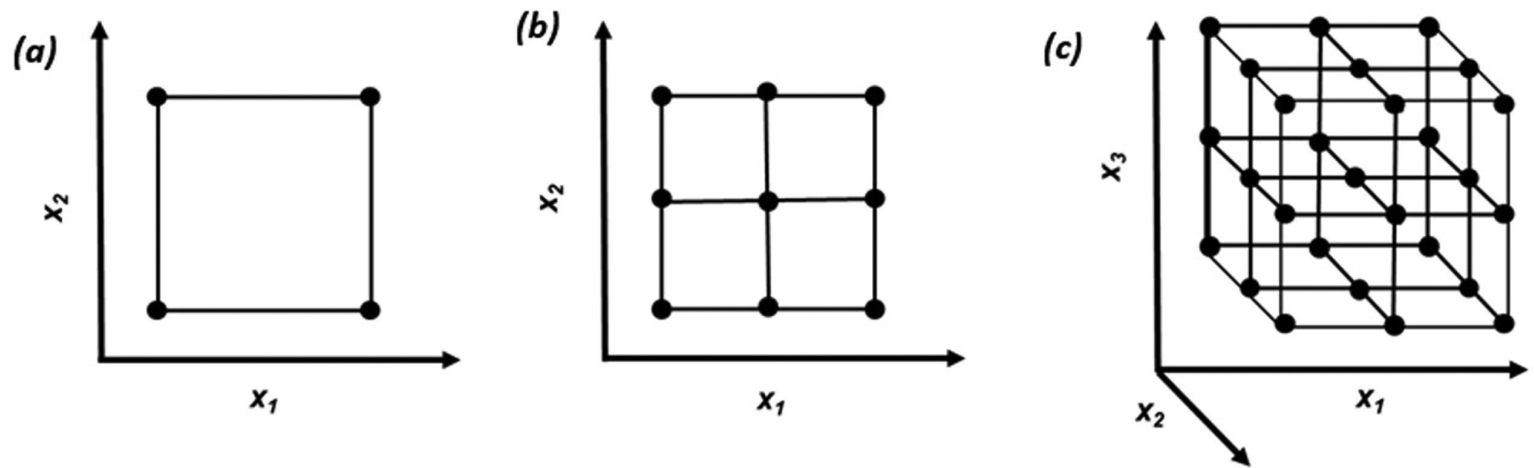

Figure 1. Illustration of factorial design models in various levels: (a) two-levels, two factors $\left(2^{2}\right)$ design; (b) three-levels, two factors $\left(3^{2}\right)$ design; and (c) three-levels, three factors $\left(3^{3}\right)$ design.

Table 2. Reports of factorial design application in natural product research.

\begin{tabular}{|c|c|c|c|}
\hline Samples & Objective of study & Types of factorial design & References \\
\hline L. pentosus & $\begin{array}{l}\text { Testing the relationship between the type and the ratio of hemicellulosic } \\
\text { sugars for producing biosurfactants }\end{array}$ & Fractional FD & (Portilla-Rivera et al., 2009) \\
\hline S. mirzayanii & $\begin{array}{l}\text { Evaluating the effect of different parameters on the microwave-assisted } \\
\text { extraction }\end{array}$ & Fractional FD & (Khajeh and Ghanbari, 2011) \\
\hline A. аппиа & Optimizing extraction process & Fractional FD & (Khalil et al., 2011) \\
\hline Ginger rhizome & Determining the optimum extraction conditions & Full $2^{3} \mathrm{FD}$ & (Shah and Garg, 2014) \\
\hline L. sidoides & Evaluating the influences of variables of preparation & Full $2^{3} \mathrm{FD}$ & (Lima et al., 2015) \\
\hline Tempeh (a fermented product from soybean) & Evaluating factors of the extraction process & Full $2^{3} \mathrm{FD}$ & (Yuliani et al., 2018) \\
\hline C. sinensis $\mathrm{L}$. & Optimizing the extraction condition & Full $2^{2} \mathrm{FD}$ & (Setyawan et al., 2018) \\
\hline Tea, coffee, and human urine & $\begin{array}{l}\text { Improving the chromatographic resolution of three methylxanthines } \\
\text { (caffeine, theobromine, and theophylline) }\end{array}$ & Full $3^{2} \mathrm{FD}$ & (de Aragão et al., 2005) \\
\hline Fresh and dry-cured pork products & Optimizing the chromatographic conditions & Full $3^{2}$ FD & (Saccani et al., 2005) \\
\hline Berberis species & Optimizing the berberine loaded liposome for oral administration. & Full $3^{2}$ FD & (Sailor et al., 2015) \\
\hline
\end{tabular}


Analysis of three methylxanthines such as caffeine, theobromine, and theophylline in the matrix of tea, coffee, and human urine was done by validated RP-HPLC/UV (de Aragão et al., 2005). Another study by Saccani et al. (2005) conducted a three-level factorial design and RSM in the optimization of a cation-exchange column and UV detection at $262 \mathrm{~nm}$ followed by validated IC-MS determination for quantitative analysis of the niacin level in fresh and dry-cured pork products (Saccani et al., 2005). These two studies presented proposed methods with good chromatographic separation from complex matrices of natural products employed by three-level factorial design and RSM. Application of the three-level full factorial design was also developed by Sailor et al. (2015) in the optimization of berberine loaded liposome.

\section{CENTRAL COMPOSITE DESIGN}

The two-level designs were useful to be applied in the screening study. However, the two-level designs lack information about maxima or any non-linear relationships since its application lead only on linear models (Hibbert, 2012). Performing a full factorial design with the level more than two will affect the effectiveness of the design itself due to the greater number of experiments that should be done. Hence, it is important to develop a design which allows greater level numbers without running every combination experiments. Presented by Box and Wilson (1951), the CCD becomes solution to overcome these problems. This design consists of three parts, namely, a full factorial or fractional factorial design, axial or star points as additional design, (a)

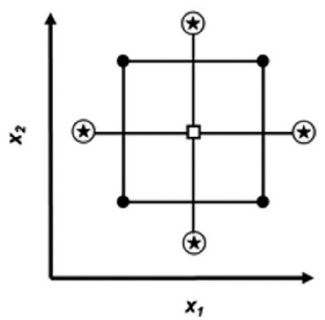

(b)

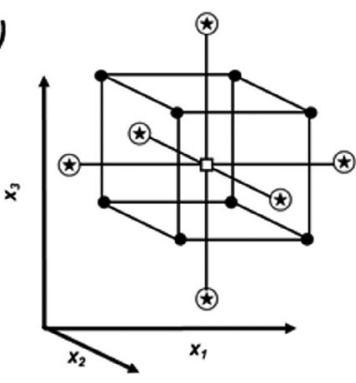

Figure 2. Illustration of central composite designs for (a) two factors and (b) three factors optimization. Every design consists of factorial points (•), star points $(\circledast)$, and central points $(\square)$ and central point with all factors set to 0 . Figure 2 illustrates the CCD. It can be seen that the factorial and star points lie equidistant from the central point. It allows the design to cover the factor space near the central point with more points than at the peripheral area of the factorial design.

The CCD has been widely applied in the field of natural product research. Table 3 presents some reports of CCD application in natural product research. These models were commonly used in several optimization purposes such as formulation, product enhancement, and separation both for extraction and chromatographic condition. Benali et al. (2014) developed natural food jelly from Phoenix dactylifera L. fruit syrup and orange albedo powder in lemon juice suspension. The effect of cooking temperature, cooking time, Brix, and cooling stage temperature has been evaluated to achieve the optimum hardness and stickiness of resulted product (Benali et al., 2014). Other related study has been conducted by Kaur et al. (2018) which optimized blending process of radish (Raphanus sativus) juice production. The CCD provided 20 formulation runs with various series concentration of herbal extract, sugarcane juice, and salt (Kaur et al., 2018).

In the aim of product enhancement, the CCD was employed as one of mathematical and statistical strategy to increase secondary metabolites production and compounds related. Farombi et al. (2018) optimized preparation conditions of hydroxyapatite from catfish bones using the CCD under the RSM (Farombi et al., 2018). This study claimed to be important since there was only limited study of hydroxyapatite extraction which can be potentially developed as long-term contaminants containment (Alpat et al., 2008; Barakat et al., 2009; Sobczak et al., 2009). Other studies related to product enhancement were dominated by biotechnological studies. Haemophilus influenzae, Streptomonospora arabica, Streptomyces rimosus, and Myroides gitamensis were investigated to become natural sources of biomass (Momen et al., 2016), antifungal agent (Managamuri et al., 2017), cholesterol oxidase enzyme (Srivastava et al., 2018), and L-asparaginase enzyme (Talluri et al., 2019), respectively.

In the field of separation science from natural products, the CCD was applied for optimization of both extraction condition and performance parameters of the chromatographic method. This design was developed in the extraction of Lotus plumule (Xiong et al., 2016), Curcuma zedoaria leaves (Azahar et al., 2017), and

Table 3. Reports of central composite design application in natural product research.

\begin{tabular}{|c|c|c|}
\hline Samples & Objective of Study & References \\
\hline P. dactylifera L.) & Optimizing formula of natural food jelly from natural ingredients & (Benali et al., 2014) \\
\hline Ericaceae plant materials & Establishing optimal separation conditions & (Owczarek et al., 2016) \\
\hline L. plumule & Optimizing MAE conditions & (Xiong et al., 2016) \\
\hline Haemophilus influenzae & Determining the optimum cultivation conditions for growth and biomass production & (Momen et al., 2016) \\
\hline C. zedoaria leaves & Maximizing the extraction yield of total phenolics and flavonoids & (Azahar et al., 2017) \\
\hline S. arabica VSM25 & Studying the impact of five variables on the production of antifungal metabolites & (Managamuri et al., 2017) \\
\hline Mango seed kernel oil & Optimizing temperature, time, and amount of n-hexane & (Mas'ud et al., 2017) \\
\hline S. rimosus & $\begin{array}{l}\text { Predicting the combination of yeast extract, dextrose, starch and ammonium carbonate } \\
\text { at various concentrations }\end{array}$ & (Srivastava et al., 2018) \\
\hline Nutritional beverage & Optimizing component in the development of nutritional beverages & (Kaur et al., 2018) \\
\hline Catfish bones & Optimizing preparation conditions for producing hydroxyapatite & (Farombi et al., 2018) \\
\hline M. gitamensis BSH-3 & Optimizing of process parameters of L-asparaginase enzyme production & (Talluri et al., 2019) \\
\hline
\end{tabular}


mango seed kernel oil (Mas'ud et al., 2017). Owczarek et al. (2016) conducted the standardization of Ericaceae medicinal plants using ultra-high performance liquid chromatography-photodiode array for determining oleanolic and ursolic acids. The CCD played an important role in separation conditions optimization. Temperature and flowrate were established as factors. On the other hand, separation time, resolution, and total response were marked as responses. This study declared that the developed method was successfully applied to evaluate the content of oleanolic and ursolic acids in Ericaceae plant samples.

\section{BOX-BEHNKEN DESIGN}

In several cases of natural product research, it is a common possibility to find problems which should be solved using mathematical model or design using three levels or more and three factors or more. Box and Behnken (1960) presented a particular class of three-level fractional factorial design with the specification for studying quantitative variables and now this finding was well known as the BBD. This design was more efficient and economical than other three-level designs due to its ability to allow points selection from the three-level factorial arrangement (Bezerra et al., 2008). The characteristics for the BBD are that there are no factorial or extreme points. This design requires fewer points than the $\mathrm{CCD}$ as it was promoted by Ferreira et al. (2007) for the optimization of analytical methods. Figure 3 illustrates the model of the BBD.
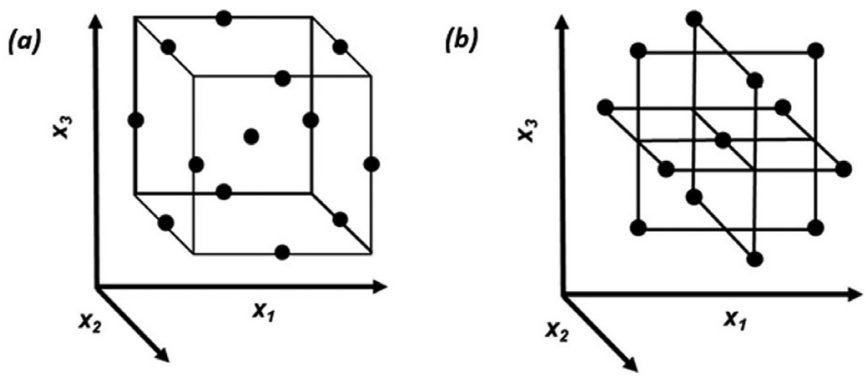

Figure 3. Illustration of the two graphical forms for the three factors BBD: (a) the cube for BBD and (b) three interlocking $2^{2}$ factorial design.
Table 4 presents some reports of BBD application in natural product research. Similar to CCD, the BBD can be applied for optimization study including extraction process, product enhancement, and chromatographic separation. These designs were widely used to optimize several parameters of extraction such as extraction time, extraction temperature, extraction number, solid to liquid ratio, solvent selection, and solvent concentration (Anuar et al., 2013; Jeong et al., 2017; Sousa et al., 2014; Yoo et al., 2018). For specific extraction technique, namely, decoction process, parameters including decocting temperature, total decocting time, and water-to-medicinal sample ratio were evaluated (Ha et al., 2018; Zhang et al., 2017). The BBD can be conducted for other special technique, namely, microwave-assisted extraction to evaluate the effect of microwave power, temperature, and solvent type (Khajeh and Ghanbari, 2011).

Abdella et al. (2018) evaluated variables for genistein production by deglycosylation process involving commercial $\beta$-glucosidase enzyme. Concentration of enzyme, agitation rate, reaction time, and $\mathrm{pH}$ has been stated as factors of experiments with 25 runs. This study has successfully obtained the optimal combination of the major reaction affecting factors to enhance genistein production (Abdella et al., 2018).

Studies on chromatography also reported the application of the BBDs with HPLC and high performance thin layer chromatography (HPTLC). Prabaningdyah et al. (2017) developed an HPLC method to determine curcumin and desmethoxy curcumin in Curcuma syrup formulation employed by the BBD with RSM. This method was successfully optimized and validated according to the International Conference on Harmonization (ICH) guidelines. Hence, this method could be applied for routine analysis of curcuminoids content in syrup formulation. The BBD was not only useful to be applied along with HPLC method but also with other chromatographic technique, namely, HPTLC. Gohel et al. (2018) conducted BBD-assisted optimization for quantitative analysis of quercetin, kaempferol, and keto- $\beta$ boswellic acid. Three HPTLC conditions including volume of $n$-hexane, solvent front, and chamber saturation time have been chosen as experimental factors to evaluate five responses related to optimum separation. This study resulted that the proposed

Table 4. Reports of BBD application in natural product research.

\begin{tabular}{|c|c|c|}
\hline Samples & Objective of Study & References \\
\hline S. mirzayanii & Optimizing conditions for extraction & (Khajeh and Ghanbari, 2011) \\
\hline Melastoma malabathricum Fruit & $\begin{array}{l}\text { Optimizing of variables for obtaining anthocyanins pigment from the extraction } \\
\text { process }\end{array}$ & (Anuar et al., 2013) \\
\hline Yukmijihwang-tang (an herbal formula) & Optimizing extraction process & (Kim et al., 2014) \\
\hline $\begin{array}{l}\text { Stryphnodendron adstringens (Mart.) Coville } \\
\text { bark extracts }\end{array}$ & Optimizing extraction parameter & (Sousa et al., 2014) \\
\hline $\begin{array}{l}\text { Ephedra intermedia, Rheum palmatum, and } \\
\text { Lithospermum erythrorhizon }\end{array}$ & $\begin{array}{l}\text { Optimizing the experimental conditions in the laboratory to extract }(-) \text {-ephedrine } \\
\text { and }(+) \text {-pseudoephedrine }\end{array}$ & (Jeong et al., 2017) \\
\hline Curcuma syrup & Optimizing HPLC condition & (Prabaningdyah et al., 2017) \\
\hline Huang-Qi-Liu-Yi Tang (an herbal formula) & Optimizing the decoction conditions & (Zhang et al., 2017) \\
\hline Soy flour & Evaluating variables for genistein production & (Abdella et al., 2018) \\
\hline S. olerace $a$ and B. serrate & Optimizing of the HPTLC conditions & (Gohel et al., 2018) \\
\hline M. officinalis $\mathrm{L}$. & Evaluating the effects of three independent variables on $M$. officinalis $\mathrm{L}$. extraction & (Yoo et al., 2018) \\
\hline
\end{tabular}


method has met the requirements for validated HPTLC method for the quality control testing of Spinacia oleracea and Boswellia serrata.

\section{DOEHLERT DESIGN}

Doehlert (1970) developed an alternative experimental design which has several advantages such as few experimental points, high efficiency, and economically effective. Different from central composite and BBDs, these designs are not rotatable due to their number of estimation for varied factors. Nevertheless, Doehlert designs have different numbers of levels for different factors and allow to fill the provided factor space uniformly according to its possibility (Hibbert, 2012). Belonging to a second-order experimental design, Doehlert designs describe different characteristics for different levels: 1) a circular domain for two variables; 2) spherical domain for three variables; and 3) hyperspherical domain for four and more variables, which accents the uniformity of the studied variables in the experimental domain (Bezerra et al., 2008). Figure 4 illustrates the model of the Doehlert design.

Table 5 presents some reports of Doehlert design application in natural product research. Although commonly applied in chromatographic optimization (Araujo and Janagap,
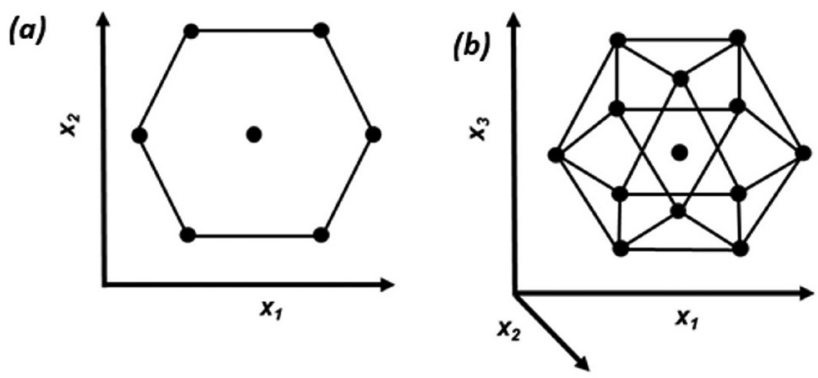

Figure 4. Illustration of the model of the Doehlert design for the optimization of (a) two variables and (b) three variables.

Table 5. Reports of Doehlert design application in natural product research.

\begin{tabular}{lll}
\hline Samples & Objective of Study & References \\
\hline Medicinal herbs & $\begin{array}{l}\text { Evaluating instrumental parameters } \\
\text { of the LIBS }\end{array}$ & (Andrade et al., 2017) \\
$\begin{array}{l}\text { S. mombin } \mathrm{L} \\
\begin{array}{l}\text { Apple Bagasse } \\
\text { Agroindustrial } \\
\text { Residues }\end{array}\end{array}$ & $\begin{array}{l}\text { Achieving the maximum response } \\
\text { for the extraction of total phenolic } \\
\text { compounds }\end{array}$ & (Santos-Felix et al., 2018) \\
$\begin{array}{l}\text { Solanaceae } \\
\text { family plants }\end{array}$ & $\begin{array}{l}\text { Optimizing extract purification } \\
\text { procedure }\end{array}$ & (Ciechomska et al., 2016) \\
$\begin{array}{l}\text { Belladona } \\
\text { extract }\end{array}$ & $\begin{array}{l}\text { Optimizing electrophoretic } \\
\text { conditions }\end{array}$ & (Mateus et al., 1998) \\
Bovine milk & $\begin{array}{l}\text { Optimizing extraction condition } \\
\text { for determining of organochlorine } \\
\text { pesticides }\end{array}$ & (Merib et al., 2014) \\
& $\begin{array}{l}\text { Optimizing the dioxane organosolv } \\
\text { Almond shells }\end{array}$ & (Quesada-Medina et al., \\
Sugar & $\begin{array}{l}\text { Optimizing experimental design } \\
\text { methodology }\end{array}$ & (Pinkowska et al., 2019) \\
$\begin{array}{l}\text { Polygonum } \\
\text { cuspidatum }\end{array}$ & $\begin{array}{l}\text { Optimizing the ultrahigh pressure } \\
\text { extraction (UPE) process }\end{array}$ & (Wang and Liu, 2005) \\
\hline
\end{tabular}

2012), this design was used in other fields of natural product and environmental research. Mateus et al. (1998) optimized the micellar electrokinetic capillary chromatography conditions using Doehlert design to determine selected tropane alkaloids. Three factors were evaluated; namely, the buffer $\mathrm{pH}$, the micelle concentration, and the acetonitrile percentage. The most favorable conditions were achieved with $30 \mathrm{mM}$ borate-phosphate buffer $(\mathrm{pH}=8.7)$, micelle concentration of $40 \mathrm{mM}$ sodium dodecyl sulfate, and $16.5 \%$ acetonitrile.

The Doehlert designs were also applied in environmental research. Merib et al. (2014) conducted the optimization of extraction condition in order to determine organochlorine pesticides residue in bovine milk employed by the Doehlert design (Merib et al., 2014). Other related study implemented Doehlert design in evaluation of instrumental parameters of the laserinduced breakdown spectroscopy (LIBS) for analyzing essential elements $(\mathrm{Ca}, \mathrm{K}$, and $\mathrm{Mg}$ ) from medicinal herbs (Andrade et al., 2017).

In extraction process optimization, Doehlert design was applied for optimizing procedure including solvent used, extraction time, temperature, and agitation speed. Various samples such as Spondias mombin L. (Santos-Felix et al., 2018), Solanaceae family plants (Ciechomska et al., 2016), and almond shells have been involved in these studies (Quesada-Medina et al., 2011). More advanced extraction techniques such as hydrothermal extraction, ultrahigh pressure extraction (UPE) were also employed by the Doehlert design (Pinkowska et al., 2019; Wang and Liu, 2005).

\section{CONCLUSION}

The RSM designs were widely applied in the field of natural product research due to their advantages compared to the traditional one-variable-at-a-time design. In recent years, there were a large number of publications related to RSM designs and their application. However, this present review focuses on basic principles of factorial designs, CCDs, BBDs, and Doehlert designs which utilized along with the RSM and their applications in natural product research.

Natural product research conducted using CCDs, BBDs, and Doehlert designs were found more frequent in the last decade compared to the full three-level factorial design. The efficiency and economic approach were assumed to be the main consideration for why the popularity of fractional design was increased nowadays. Optimization of the extraction process and analytical method development were found to be the most popular consideration on generating the RSM in the natural product research due to their ability to evaluate the interactive effects among different variables. Although, other considerations such as secondary metabolite production and related compound enhancement as well as environmental assessment encouraged researchers to utilize the RSM models.

Finally, RSM models combined with experimental design can be employed as mathematical and statistical tools in natural product research. This strategy was not only good in the optimization process but also proved to be validated for the analytical method and effective for product enhancement in natural product research. 


\section{ACKNOWLEDGMENT}

The authors are grateful to the Faculty of Pharmacy, Gadjah Mada University, Yogyakarta, Indonesia for the provided facilities. This review article was a part of research funded by Thesis Recognition Program 2019, Directorate of Research, Gadjah Mada University (No.: 3034/UNI/DITLIT/DIT-LIT/ LT/2019), awarded to Prof. Dr. Sudibyo Martono.

\section{CONFLICT OF INTEREST}

All the authors declared there is no conflict of interest.

\section{AUTHORS' CONTRIBUTION}

FDOR carried out the literature search, investigation, and initial draft writing. AR reviewed the initial draft and carried out content supervising in the field of chemometrics, analytical chemistry, and computational statistics. SP reviewed the initial draft and carried out content supervising in the field of natural product research and separation science. SM provided the conceptualization of the article, reviewed the initial draft, and carried out content supervising in the field of analytical chemistry and analytical instrumentations.

\section{REFERENCES}

Abdel-Rahman A, Anyangwe N, Carlacci L, Casper S, Danam RP, Enongene E, Erives G, Fabricant D, Gudi R, Hilmas, CJ, Hines F, Howard P, Levy D, Lin Y, Moore RJ, Pfeiler E, Thurmond TS, Turujman S, Walker NJ. The safety and regulation of natural products used as foods and food ingredients. Toxicol Sci, 2011; 123(2):333-48.

Abdella A, El baz AF, Mahrous EE, El Maksoud AAA, Ibrahim IA, Abdel-Monem AR, Yang S-T. Response surface methodology for optimization of genistein content in soy flour and its effect on the antioxidant activity. Iran J Pharm Res, 2018; 17(July 2015):1026-35.

Aghamohammadi A, Hosseinimehr SJ. Antiangiogenic agents in natural products for the treatment of gynecologic disorders. Nutr Cancer, 2014; 66(2):206-13.

Alpat SK, Özbayrak Ö, Alpat Ş, Akçay H. The adsorption kinetics and removal of cationic dye, Toluidine Blue $\mathrm{O}$, from aqueous solution with Turkish zeolite. J Hazard Mater, 2008; 151(1):213-20.

Andrade DF, Pereira-Filho ER, Konieczynski P. Comparison of ICP OES and LIBS analysis of medicinal herbs rich in flavonoids from Eastern Europe. J Braz Chem Soc, 2017; 28(5):838-47.

Anuar N, Mohd Adnan AF, Saat N, Aziz N, Mat Taha R. Optimization of extraction parameters by using response surface methodology, purification, and identification of anthocyanin pigments in Melastoma malabathricum fruit. Sci World J, 2013; 2013:1-10.

de Aragão NM, Veloso MCC, Bispo MS, Ferreira SLC, De Andrade JB. Multivariate optimisation of the experimental conditions for determination of three methylxanthines by reversed-phase highperformance liquid chromatography. Talanta, 2005; 67(2005):1007-13.

Araujo P, Janagap S. Doehlert uniform shell designs and chromatography. J Chromatogr B Anal Technol Biomed Life Sci, Elsevier B.V., 2012; 910(2012):14-21.

Azahar NF, Salwa S, Gani A, Fadzillah N, Mokhtar M. Optimization of phenolics and flavonoids extraction conditions of Curcuma Zedoaria leaves using response surface methodology. Chem Cent J, Springer International Publishing, 2017; 11(96):1-10.

Barakat NAM, Khil MS, Omran AM, Sheikh FA, Kim HY Extraction of pure natural hydroxyapatite from the bovine bones bio waste by three different methods. J Mater Process Technol, 2009; 209(7):3408-15.

Behera SK, Meena H, Chakraborty S, Meikap BC. Application of response surface methodology (RSM) for optimization of leaching parameters for ash reduction from low-grade coal. Int J Min Sci Technol, China University of Mining \& Technology, 2018; 28(4):621-9.
Benali S, Benamara S, Bigan M, Madani K. Feasibility study of date (Phoenix dactylifera $\mathrm{L}$.) fruit syrup-based natural jelly using central composite design. J Food Sci Technol, 2014; 52(8):4975-84.

Bernardini S, Tiezzi A, Laghezza Masci V, Ovidi E. Natural products for human health: an historical overview of the drug discovery approaches. Nat Prod Res, Taylor \& Francis, 2018; 32(16):1926-50.

Bezerra MA, Santelli RE, Oliveira EP, Villar LS, Escaleira LA. Response surface methodology (RSM) as a tool for optimization in analytical chemistry. Talanta, 2008; 76(5):965-77.

Box GEP, Behnken DW. Some new three level designs for the study of quantitative variables some new three level designs for the study of quantitative variables. Technometrics, 1960; 2(4):455-75.

Box GEP, Wilson KB. On the experimental attainment of optimum conditions. J R Stat Soc Ser B, 1951; 13(1):1-45.

Breitling R, Ceniceros A, Jankevics A, Takano E. Metabolomics for secondary metabolite research. Metabolites, 2013; 3(4):1076-83.

Brereton RG. Applied chemometrics for scientists. Appl. Chemom. Sci. John Wiley \& Sons, Ltd, Chichester, UK, 2007.

Burgess A, Glasauer P. Family nutrition guide [Internet]. Food and Agriculture Organization of the United Nations, Rome, Italy, pp 1-126, 2004.

Choi HJ, Park DH, Song SH, Yoon IS, Cho SS. Development and validation of a HPLC-UV Method for extraction optimization and biological evaluation of hot-water and ethanolic extracts of dendropanax morbifera leaves. Molecules, 2018; 23(3):650.

Ciechomska M, Woźniakiewicz M, Nowak J, Świadek K, Bazylewicz B, Kościelniak P. Development of a microwave-assisted extraction of atropine and scopolamine from Solanaceae family plants followed by a QuEChERS cleanup procedure. J Liq Chromatogr Relat Technol, 2016; 39(11):538-48.

Dias DA, Urban S, Roessner U. A historical overview of natural products in drug discovery. Metabolites, 2012; 2(2):303-36.

Doehlert DH. Uniform shell designs. Appl Stat, 1970; 19(3):

$231-9$

Farombi AG, Amuda OS, Alade AO, Okoya AA, Adebisi SA Central composite design for optimization of preparation conditions and characterization of hydroxyapatite produced from catfish bones. Beni-Suef Univ J Basic Appl Sci, Elsevier B.V., 2018; 7(4):474-80.

Ferreira SLC, Bruns RE, Ferreira HS, Matos GD, David JM, Brandão GC, da Silva EGP, Portugal LA, dos Reis PS, Souza AS, dos Santos WNL. Box-Behnken design: An alternative for the optimization of analytical methods. Anal Chim Acta, 2007; 597(2):179-86.

Gohel K, Patel K, Shah P, Hingorani L, Gandhi T. Box-Behnken design-assisted optimization for simultaneous estimation of quercetin, kaempferol, and keto- $\beta$-boswellic acid by high-performance thin-layer chromatography method. J Planar Chromatogr, 2018; 31(4):318-26.

Ha W-R, Park J-H, Kim J-H. Optimization for decocting later of menthae herba in eungyo-san, a herbal formula, using response surface methodology with gas chromatography/mass spectrometry. Pharmacogn Mag, 2018; 14(53):17-21.

Hamzah H, Tunjung Pratiwi SU, Hertiani T. Efficacy of thymol and eugenol against polymicrobial biofilm. Indones J Pharm, 2018; 29(4):214-21.

Handayani D, Aminah I. Antibacterial and cytotoxic activities of ethyl acetate extract of symbiotic fungi from West Sumatra marine sponge Acanthrongylophora ingens. J Appl Pharm Sci, 2017; 7(2):237-40.

Hibbert DB. Experimental design in chromatography: a tutorial review. J Chromatogr B Anal Technol Biomed Life Sci, Elsevier B.V., 2012; 910:2-13.

Hunter-Cevera J, Gleba Y, Goodman R, Padgett HS. Opportunities and challenges for plant natural product research and development. Ind Biotechnol, 2014; 10(5):338-42.

Jeong B, Choi SY, Jang HS, Yoo G, Kim SH, Kim JH, Kwon YS, Roh JS, Yoon Y, Shin SS, Yang H. Optimization of extraction conditions for active compounds of herbal medicinal formula, DF, by response surface methodology. Nat Prod Sci, 2017; 23(1):9-15. 
Kaur G, Kumar V, Goyal A, Tanwar B, Kaur J. Optimization of nutritional beverage developed from radish, sugarcane and herbal extract using response surface methodology. Nutr Food Sci, 2018; 48(5):733-43.

Khajeh M, Ghanbari A. Application of factorial design and Box-Behnken matrix in the optimisation of a microwave-assisted extraction of essential oils from Salvia mirzayanii. Nat Prod Res, 2011; 25(18):1766-70.

Khalil M, Darusman LK, Syafitri UD. Application of fractional factorial design to optimize extraction method of artemisinin from Artemisia аппиа. ScienceAsia, 2011; 37(3):219-24.

Kim JH, Shin HK, Seo CS. Optimization of the extraction process for the seven bioactive compounds in Yukmijihwang- tang, an herbal formula, using response surface methodology. Pharmacogn Mag, 2014; 10(39):606-13.

Li G, Lou HX. Strategies to diversify natural products for drug discovery. Med Res Rev, 2018; 38(4): 1255-94.

Lima BS, Ramos CS, Santos JPA, Rabelo TK, Serafini MR, Souza CAS, Soares LAL, Quintans LJ, Moreira JCF, Gelain DP, Araújo AAS, Silva FA. Development of standardized extractive solution from Lippia sidoides by factorial design and their redox active profile. Brazilian J Pharmacogn, Sociedade Brasileira de Farmacognosia, 2015; 25(3):301-6.

Luneeva OL, Zakirova VG. Integration of mathematical and natural-science knowledge in school students' project-based activity. Eurasia J Math Sci Technol Educ, 2017; 13(7):2821-40.

Mahdi JG. Medicinal potential of willow: A chemical perspective of aspirin discovery. J Saudi Chem Soc, King Saud University, 2010; 14(3):317-22.

Managamuri U, Vijayalakshmi M, Poda S, Ganduri VSRK, Rajulapati SB. Optimization of operating conditions for the production of enhanced antifungal metabolites from Streptomonospora arabica VSM 25 by full factorial design. J Young Pharm, 2017; 9(3):399-409.

Mas'ud F, Mahendradatta M, Laga A, Zainal Z. Optimization of mango seed kernel oil extraction using response surface methodology. OCL, 2017; 24(5):D503.

Mateus L, Cherkaoui S, Christen P, Veuthey JL. Use of a Doehlert design in optimizing the analysis of selected tropane alkaloids by micellar electrokinetic capillary chromatography. J Chromatogr A, 1998; 829(1-2):317-25.

Merib J, Nardini G, Carasek E. Use of Doehlert design in the optimization of extraction conditions in the determination of organochlorine pesticides in bovine milk samples by HS-SPME. Anal Methods, 2014; 6(10):3254-60.

Miller JM, Miller JC. Statistics and chemometrics for analytical chemistry. Technometrics, 2010; 186-220.

Mojab F. Antimalarial natural products: a review. Avicenna J phytomedicine, 2012; 2(2):52-62.

Moloney MG. Natural products as a source for novel antibiotics. Trends Pharmacol Sci, 2016; 37(8):689-701.

Momen SB, Siadat SD, Akbari N, Ranjbar B, Khajeh K. Applying central composite design and response surface methodology to optimize growth and biomass production of haemophilus influenzae type $b$. Jundishapur J Microbiol, 2016; 9(6):1-6.

Myers RH, Montgomery DC, Anderson-Cook CM. Response surface methodology: process and product optimization using designed experiments. $3^{\text {rd }}$ edition, John Wiley Sons, Ltd. New Jersey, 2009.

Newman DJ, Cragg GM. Natural Products as Sources of New Drugs from 1981 to 2014. J Nat Prod, 2016; 79(3):629-61.

Newman DJ, Cragg GM, Snader KM. The influence of natural products upon drug discovery. Nat Prod Rep, 2000; 17(3):215-34.

Owczarek A, Kuźma Ł, Wysokińska H, Olszewska M. Application of response surface methodology for optimisation of simultaneous UHPLC-PDA determination of oleanolic and ursolic acids and standardisation of Ericaceae medicinal plants. Appl Sci, 2016; 6(9):244.

Parodi A, Leip A, De Boer IJM, Slegers PM, Ziegler F, Temme EHM, Herrero M, Tuomisto H, Valin H, Van Middelaar CE, Van Loon JJA, Van Zanten HHE. The potential of future foods for sustainable and healthy diets. Nat Sustain, 2018; 1(12):782-9.
Pinkowska H, Krzywonos M, Wolak P, Złocinska A. Pectin and neutral monosaccharides production during the simultaneous hydrothermal extraction of waste biomass from refining of sugar - optimization with the use of Doehlert design. Molecules, 2019; 24(472):1-11.

Portilla-Rivera OM, Torrado-Agrasar A, Carballo J, Domínguez JM, Moldes AB. Development of a factorial design to study the effect of the major hemicellulosic sugars on the production of surface-active compounds by L. pentosus. J Agric Food Chem, 2009; 57(19):9057-62.

Prabaningdyah NK, Riyanto S, Rohman A, Siregar C. Application of HPLC and response surface methodology for simultaneous determination of curcumin and desmethoxy curcumin in Curcuma syrup formulation. J Appl Pharm Sci, 2017; 7(12):58-64.

Puspita R, Bintang M, Priosoeryanto BP. Antiproliferative activity of longan (Dimocarpus longan Lour.) leaf extracts. J Appl Pharm Sci, 2019; 9(5):102-6.

Quesada-Medina J, Olivares-Carrillo P, López-Cremades FJ. Application of a Doehlert experimental design for optimizing the dioxane organosolv extraction of lignin from hydrolyzed almond shells. Afinidad, 2011; 68(552):107-15.

Riswanto FDO, Hariono M, Yuliani SH, Istyastono EP Computer-aided design of chalcone derivatives as lead compounds targeting acetylcholinesterase. Indones J Pharm, 2017; 28(2):100-11.

Saccani G, Tanzi E, Mallozzi S, Cavalli S. Determination of niacin in fresh and dry cured pork products by ion chromatography: Experimental design approach for the optimisation of nicotinic acid separation. Food Chem, 2005; 92(2005):373-9.

Sailor G, Seth AK, Parmar G, Chauhan S, Javia A. Formulation and in vitro evaluation of berberine containing liposome optimized by $3^{2}$ full factorial designs. J Appl Pharm Sci, 2015; 5(7):23-8.

Santos-Felix AC, Novaes CG, Pires Rocha M, Barreto GE, do Nascimento BB, Giraldez Alvarez LD. Mixture design and Doehlert matrix for the optimization of the extraction of phenolic compounds from Spondias mombin L Apple Bagasse Agroindustrial Residues. Front Chem, 2018; 5(January): $1-8$

Sarker SD, Nahar L. Chemistry for pharmacy students: general, organic, and natural product chemistry. Chem Pharm Students Gen Org Nat Prod Chem, p 396, 2007

Sen GA. Application of full factorial experimental design and response surface methodology for chromite beneficiation by Knelson Concentrator. Minerals, 2016; 6(1):5.

Setyawan EI, Rohman A, Setyowati EP, Nugroho AK Application of factorial design on the extraction of green tea leaves (Camellia sinensis L.). J Appl Pharm Sci, 2018; 8(4):131-8.

Shah M, Garg SK. Application of $2 \mathrm{k}$ full factorial design in optimization of solvent-free microwave extraction of ginger essential oil. J Eng, 2014; 2014:828606.

Shan JJ, Rodgers K, Lai CT, Sutherland SK. Challenges in natural health product research: The importance of standardization. Proc West Pharmacol Soc, 2007; 2007(50):24-30.

Siregar C, Prabaningdyah NK, Choiri S, Riyanto S, Rohman A. Optimization of HPLC using central composite design for determination of curcumin and demethoxycurcumin in tablet dosage form. 2017; 16(2):137-45.

Soares-Bezerra RJ, Calheiros AS, Ferreira NC da S, Frutuoso V da S, Alves LA. Natural products as a source for new anti-inflammatory and analgesic compounds through the inhibition of purinergic P2X receptors. Pharmaceuticals, 2013; 6(5):650-8.

Sobczak A, Kowalski Z, Wzorek Z. Preparation of hydroxyapatite from animal bones. Acta Bioeng Biomech, 2009; 11(4):23-8.

Sousa JN, Pedroso NB, Borges LL, A. G, Paula JR, Conceicao EC. Optimization of ultrasound-assisted extraction of polyphenols, tannins and epigallocatechin gallate from barks of Stryphnodendron adstringens (Mart.) Coville bark extracts. Pharmacogn Mag, 2014; 10(38):318-23.

Srivastava A, Singh V, Haque S, Pandey S, Mishra M, Jawed A, Shukla PK, Singh PK, Tripathi CKM. Response surface methodologygenetic algorithm based medium optimization, purification, and characterization of cholesterol oxidase from Streptomyces rimosus. Sci Rep, Springer US, 2018; 8(10913):1-13. 
Talluri VP, Lanka SS, Saladi VR. Statistical optimization of process parameters by Central Composite Design ( CCD ) for an enhanced production of L-asparaginase by Myroides gitamensis BSH-3, a novel species. Avicenna J Med Biotechnol, 2019; 11(7):59-66.

Thirumurugan D, Cholarajan A, Raja SSS, Vijayakumar R. An introductory chapter: secondary metabolites. Second metab - sources Appl, pp 1-21, 2018

Vera-Candioti L, De Zan MM, Cámara MS, Goicoechea HC. Experimental design and multiple response optimization. Using the desirability function in analytical methods development. Talanta, Elsevier, $2014 ; 124: 123-38$.

Wang D-G, Liu W-Y. Application of Doehlert design for the optimization of resveratrol extraction from Polygonum cuspidatum. Chinese Pharm J, 2005; 15.

Xiong W, Chen X, Lv G, Hu D, Zhao J, Li S. Optimization of microwave-assisted extraction of bioactive alkaloids from Lotus plumule using response surface methodology. J Pharm Anal, 2016; 6(2016):382-8.

Yoo G, Lee IK, Park S, Kim N, Park J, Kim S. Optimization of extraction conditions for phenolic acids from the leaves of Melissa officinalis L. using response surface methodology. Pharmacogn Mag, 2018; 14(54):155-61
Yuliani SH, Gani MR, Istyastono EP, Riswanto FDO. Optimization of genistein and daidzein extraction from a tempeh- fermented product of soybean. J Pharm Pharmacogn Res, 2018; 6(4):231-41.

Yuliani SH, Istyastono EP, Riswanto FDO. The Cytotoxic Activity on T47D Breast Cancer Cell of Genistein-Standardized Ethanolic Extract of Tempeh - A Fermented Product of Soybean ( Glycine max ). Orient J Chem, 2016; 32(3):1619-24.

Zhang XF, Yang JL, Chen J, Shi YP. Optimization of a decoction process for an herbal formula using a response surface methodology. $\mathrm{J}$ AOAC Int, 2017; 100(6):1776-84.

\section{How to cite this article:}

Riswanto FDO, Rohman A, Pramono S, Martono S. Application of response surface methodology as mathematical and statistical tools in natural product research. J Appl Pharm Sci, 2019; 9(10):125-133. 